\title{
La Comedia de Magia y los efectos visuales de la era pre-cinematográfica en el siglo XIX en Chile
}

\author{
The Comedy of Magic and the Visual Effects of the \\ Pre-cinematography Era in the XIX Century in Chile
}

\author{
Carmen Luz Maturana \\ Pontificia Universidad Católica de Chile, \\ Facultad de Letras. Santiago, Chile \\ cmaturaa@uc.cl
}

\begin{abstract}
Resumen • A través de la revisión bibliográfica, principalmente de diarios, revistas y afiches de espectáculos presentados en el siglo XIX en Santiago y otras ciudades chilenas, se configura un conjunto de obras y grupos teatrales, principalmente compañías europeas, que utilizaron efectos pre-cinematográficos para mostrar mundos escénicos vinculados a las transformaciones mágicas en vivo, producidas por efectos ópticos de proyección lumínica. Estos espectáculos tuvieron vigencia durante todo el siglo analizado. Lideraba el uso de estos efectos en la puesta en escena la Comedia de Magia. Este género, considerado como parte del fin del Barroco en Europa, tuvo su fundamento principal en la tramoya y la magia escénica. Luego, estos espectáculos desaparecieron del ámbito teatral, siendo absorbidos sus efectos ópticos por el lenguaje del cine.
\end{abstract}

Palabras clave: comedia de magia, efectos ópticos, teatro del siglo XIX.

Abstract - Through the bibliographic review of newspapers, magazines and announcements posted during the XIX Century in Santiago and other Chilean cities, it can be seen that a number of plays and some artistic groups, mainly European theater companies, used pre-cinematographic effects on stage to show how theatrical sceneries linked to live magical transformations produced by light-projected optical effects. These plays were showed throughout the whole analyzed century. Optical effects led their scenery. This genre, considered as part of the end of European baroque, had as main foundation both stage machinery and stage magic. With time, these shows disappeared from the stages since they were assimilated by the optical language of Cinema.

Keywords: comedy of magic, optical effects, theater of the XIX century.

El artículo surge a raíz de conclusiones provenientes de una investigación financiada por el FONDART 2007, Proyecto núm. 44217, relativa al Teatro de Sombras en Chile. 
Es posible remitirse a la "prehistoria» del cine por medio del teatro del siglo XIX, ya que algunas obras de ese período utilizaban efectos ópticos de la era pre-cinematográfica (panoramas, cosmoramas, fantasmagorías) para conformar realidades escénicas marcadas por la magia y las transformaciones. El inicio de estos experimentos visuales fue la linterna mágica, aparato óptico cuyo principio consiste en la proyección invertida de imágenes desde el interior de una caja oscura hacia una superficie exterior, todo esto agrandado por el uso de lentes ópticos. En Occidente, la linterna mágica fue dada a conocer hacia 1640 por el jesuita alemán Athanasius Kircher, quien la utilizó para mostrar a los fieles visiones aterradoras del infierno. De esta manera, lograba conmoverlos para que optaran por vivir de acuerdo a los preceptos cristianos. Posteriormente, este descubrimiento de proyección fue perfeccionado y utilizado, incluso hasta el siglo XIX, para espectáculos de fantasmagorías y otras visiones macabras, que atraían y horrorizaban al mismo tiempo al público.

Existe un importante material contenido en los avisos de prensa de la época que permite indagar en los orígenes del teatro visual chileno, evidenciando nexos que permitirían, en un estudio posterior, concretar la refracción del signo teatral desde la perspectiva bajtiniana, evidenciando relaciones de sentido entre diversos enunciados, adquiriendo así un carácter dialógico. El género de la Comedia de Magia desapareció de los escenarios a inicios del siglo XX, frente al recién creado lenguaje del cine:

Los influjos que aportan las comedias de magia aparecerían reseñados en varias escenas de los tempranos filmes, si bien donde se puede observar una clara influencia es en el tema del Viaje a la luna, que era uno de los motivos que ya se habían representado en las plateas de los teatros y que volverían a ser retomados en el cine desde las primeras películas del citado Mélies y continuado más adelante por prestigiosos directores, como el caso de Fritz Lang, en el período del cine silente (Gómez, 2002: 105).

Una vez llegado el siglo XX, los trucos ópticos y efectos de sombras son asimilados por el cine, el que se alimentó además de otras fuentes teatrales, como los números de ilusionismo y varietés. Este último término se utiliza en Hispanoamérica para designar un espectáculo teatral ligero, en el que se alternan números de diverso carácter como zancos, acrobacias, marionetas, muñecos autómatas, sombras, música y otra serie de lenguajes escénicos mostrados de manera combinada. Ambos tipos de representación fueron exhibidos en nuestro país durante todo el siglo XIX, principalmente en espectáculos venidos desde Europa que utilizaban efectos ópticos de proyección.

En la transcripción del material de prensa utilizado en este estudio, así como de los afiche contenidos en el Conjunto de Programas de Teatro, ambos del siglo XIX y recopilados en la Biblioteca Nacional, se ha conservado la representación gráfica original. ${ }^{2}$ Nos referiremos a algunos hitos escénicos, con la intención de abarcar un panorama general del período.

Sólo en 1927 el gobierno chileno decreta por ley a la ortografía académica como oficial en el territorio nacional. Las inconsistencias ortográficas se explican en el contexto del debate ortográfico que se desarrolló en Chile desde 1843 hasta 1927 (Alfaro et al. 2008: 121). 


\section{LA COMEDIA DE MAGIA}

Este tipo de teatro visual está fuertemente marcado por la presencia de una serie de efectos mágicos que eran del gusto del auditorio, aunque fuertemente criticados por los medios oficiales, por apelar a la superchería y a la falta de racionalidad. Las Comedias de Magia, que se desarrollaron en Europa durante los siglos XVIII y XIX, tuvieron difusión tanto en Chile como en el resto de América. El género, considerado como parte del fin del Barroco en Europa, tuvo su fundamento escénico en la tramoya y la magia en la escena. Era un tipo de espectáculo que, en determinadas obras, estaba relacionado con los artificios pre-cinematográficos, por el uso de aparatos, técnicas y artilugios audiovisuales que posteriormente configuraron el nacimiento de la exhibición cinematográfica. Escenas de magia, transformaciones, pactos diabólicos, mutaciones para efectos espantosos, exageración escenográfica y efectismos formaban parte de estos montajes: «movilidad que parece cinematográfica», dice Valbuena Prat (1956: 435) en referencia a una comedia de magia de Salvó y Vela, escrita en el siglo XVII en España. Es importante señalar que no todas las comedias de magia utilizaban efectos escénicos pre-cinematográficos. Pero las que sí, usaban trucos ópticos como parte de la tramoya escenográfica o «aparato», según la terminología de la época.

Por ejemplo, se recurría a la representación de vuelos, apariciones y desapariciones de seres que cobraban vida, como los esqueletos en las exhibiciones de fantasmagoría, para ello era necesario recurrir a instrumentos basados en la linterna mágica. También se efectuaban juegos de sombras en paredes con influencias de sombras chinescas y javanesas (Gómez, 2002: 96).

Una vez lograda en Chile la Independencia de la Corona española, se registra una serie de elementos visuales en la escena, vinculados al género teatral de las Comedias de Magia y los números de varietés. Estos espectáculos, que contenían trucos escénicos mágicos y macabros, fueron vilipendiados en general por la élite pero contaron con el aprecio y gusto del público. En Chile, este género tuvo entusiastas espectadores. Principalmente, se mostraban transformaciones escénicas por medio de linternas mágicas, las que eran utilizadas también para proyecciones de fantasmagorías, es decir, la representación ante el público de espectros y fantasmas por medio de la ilusión óptica. En nuestro país una presentación de este tipo incluso llegó a generar un escándalo «por subversión».

\section{FÉLIX TIOLA}

Sabemos que un italiano llamado Félix Tiola llegó a Santiago durante 1821, proveniente de Buenos Aires. Se anunció a través de la prensa como profesor de física divertida. El 22 de septiembre de ese año apareció un aviso de prensa donde Tiola se presenta:

tiene el honor de anunciar a este respetable público, que habiendo trabajado en Europa en las mejores fábricas de París, y de Ginebra en el arte mecánico de relojería, ofrece a este público sus servicios de componer toda clase de relojes, sean de escape como de música, y cajas de música, y todo lo que pertenece al arte mecánico [...]. Si en esta capital hubiese 
algunos aficionados que quisiesen aprender las pruebas que contiene el gabinete de física de éste, se ofrece a enseñarlos y construir las máquinas necesarias para ella, a un precio cómodo para todo aficionado (Feliú, 1964: 347-8).

Un par de años más tarde, en 1824, el día 4 y 5 de abril, presentó en Santiago un espectáculo de fantasmagoría que generó tal escándalo que se llegó a solicitar la prohibición el género de las Comedias de Magia. En el acta del Senado, sesión 52, del 7 de abril de 1824, se registra:

A mocion de uno de sus miembros, se ha penetrado de lo mucho que han ofendido la moral pública los espectáculos de fantasmagoría presentados en el teatro, los dias cuatro i cinco del corriente, i considerando que una de sus principales atribuciones [del senado] es conservar i fomentar aquéllas, alejando con sérias mediadas cuanto pueda corromperlas, ha acordado se oficie a V.E., encargándole a las autoridades competentes hagan las mas vivas investigaciones para conocer el autor de aquéllos, i que se le castigue, como corresponde a la gravedad del delito, encargándole igualmente tome medidas precautivas, para evitar en lo sucesivo escándalos de esta clase (Letelier, 1887: 242).

¿Qué había suscitado esa reacción en contra de Tiola? Presentó veinticuatro cuadros relacionados con el pueblo chileno, los que estaban enriquecidos visualmente debido a sus conocimientos de física y óptica. Uno de ellos generó el escándalo:

se dejó ver a la Diosa Cagliopo sentada sobre un sepulcro adornado de jazmines y mirtos y elevado sobre un tumulo de enlutados tambores, escribiendo en su gran rejistro lo siguiente: HOY MANUEL RODRIGUEZ SALVO A LA PATRIA. Las vivas, y aclamaciones de los espectadores a las cenizas de este héroe, fueron ilimitadas. Se pidió su repetición para contemplar con lágrimas en los ojos una memoria tan grata y execrar á sus verdugos, renovandose en sus corazones el augusto monumento que supo erigirle la gratitud por los servicios que prestó en aquellos dias a la Nacion precipitada al borde de un eminente peligro. Dias memorables en que los laureles conseguidos en el campo de honor, se matizaron con la sangre de Rodriguez vertida alevosamente sobre la tierra que acababa de libertar, y cuyos grandes echos de heroísmo no pudieron mirar sus asesinos sin la emulación propia de almas que no conocieron jamás el camino de la virtud, por donde condujo á sus compatriotas a vencér a los fieros opresores de su patria (El Avisador Chileno, 10 abril 1824, «Cinco de Abril: Teatro», s/a, N 3: 22-23).

A la fecha de la sesión legislativa, gobernaba el país como Director Supremo Ramón Freire, quien sucedió a la junta de gobierno provisoria en la que había abdicado O’Higgins, Director Supremo de la Nación a la muerte del popular guerrillero. Después de lo acontecido, el Congreso solicitó al Gobierno prohibir este género de representación teatral (Letelier, 1887: 242).

\section{EXPERIMENTOS ÓPTICOS Y PANORAMAS}

Los experimentos ópticos llamaban la atención del público y eran considerados un espectáculo en sí mismos. Por esos días se anunciaba con asombro que en Estados Unidos existía un objeto que aumentaba ocho millones de veces los objetos sometidos a su acción. 
Para mayor comodidad de los espectadores el autor ha imaginado un aparato por cuyo medio los objetos aumentados por los vidrios se reflejan en una gran superficie blanca, de modo que se goza de tan interesante espectáculo como de una representación teatral ( $E l$ Mercurio Chileno, 1 marzo 1829 «Variedades. Optica», s/a, No XII: 575).

Los panoramas eran lienzos de grandes proporciones y presentados en una sala oscura donde se realizaban proyecciones estáticas, mostrando una perspectiva parcial o total de una escena o de un paisaje proyectado o pintado circularmente. En el centro se colocaba el espectador, obteniendo una ilusión de realidad. Esta denominación produjo una cantidad de géneros derivados de la misma raíz etimológica tales como los diafanoramas, dioramas, cosmoramas, cicloramas, etc.

A principios de 1831 se anunció al público de Valparaíso una sala de panoramas con vistas traídas desde Europa.

El empresario del establecimiento Baños, Café y Fonda del Comercio, acaba de acomodar un salón, cubierto con toldo para los refrescos, que se iluminará bien todas las noches, a satisfacción de las personas que quieran favorecerlo con su concurrencia. Habiendo adquirido un panorama, ha preparado en ese salón un sitio cómodo para colocarle: en él se verán varias de las grandes ciudades de Francia, batallas de Napoleón y refriegas del pueblo de la revolución antigua de Francia (Hernández, 1928: 67).

Los efectos visuales también eran integrados a los espectáculos de varietés, conformados, como hemos visto, por una serie de números diferentes. En Valparaíso estuvieron en 1835, a fines de enero y durante febrero, en la plaza del Arsenal, el señor y la señora Robert, anunciados como "artistas de París, acabados de llegar a esta ciudad» (Hernández, 1928: 83), provenientes de México y Lima, según los anuncios de prensa. En Santiago realizaron una serie de funciones entre marzo y abril. Además de los números de física, presentaron, entre otros, «ilusiones mágicas muy divertidas» (El Araucano, 6 marzo 1835, «Teatro Gran Función», s/a, N² 234: 4) y números de nigromancia, práctica que pretende invocar a espíritus con el fin de adivinar el futuro. Éstas se realizaban por medio de espejos que reflejaban la imagen del actor sobre una pantalla o sobre otro espejo. Las visiones eran difusas, lo que aumentaba la sensación fantasmagórica de los personajes presentados. Para la última función se anunció un número que jugaba con los efectos ópticos:

la famosa prueba de májica negra jamas vista en el pais nombrada el NON PLUS ULTRA. Que consiste en que el señor Robert hará pasar por debajo de un cubilete grande, una señora con la misma facilidad que juega con las bolitas en los cubiletes pequeños. El señor Robert, convencido de ser esta suerte una de las mas extraordinarias de la destreza, se permite el honor de dedicar su ejecución al bello sexo chileno (El Araucano, 16 abril 1835 «Teatro»s/a, $\mathrm{N}^{\circ}$ 241: 4).

El nombre utilizado por estos artistas puede ser vinculado con un famoso creador de imágenes fantasmagóricas. Se trata de Robertson, cuyas proyecciones se mostraron en París en 1789, ante un público que no fue capaz de descifrar los mecanismos utilizados en la proyección de estas imágenes macabras y fantásticas, 
con abundancia de diablos, esqueletos cabalgando a caballo o con la hoz y el reloj de arena, monstruos alados, figuras grotescas, tumbas y todo lo que rodea a la muerte. Como acompañamiento, una música fúnebre, sonido de campanas, lluvia y tormenta. En fin, un verdadero espectáculo de ultratumba (Ruiz et al., 1986: 63).

En Valparaíso se anunció el 26 de junio de 1839 la llegada de un gran cosmorama desde París, «[e]n el que se exhibirán en diversas representaciones: los principales puertos de mar, batallas terrestres y navales, funciones sagradas, vistas de las primeras metrópolis y paisajes escogidos y del mejor gusto» (Hernández, 1928: 100). Las vistas de imágenes presentadas tenían relación con ciudades y eventos europeos, tales como «La Gran Torre de Londres», «La Consagración de Napoleón», «El puente Nuevo de Burdeos», «El juramento del Clero en presencia del primer Cónsul Bonaparte» (Hernández, 1928: 100). Cada cuatro días se cambiaban las vistas, y todos los días había función: "Se dará principio a las 5 de la tarde hasta las 10, en la casa bajo los altos de la Fonda de Comercio en la Plaza» (100).

\section{LA NONA SANGRIENTA}

Otra Comedia de Magia que generó algún escándalo fue La Nona Sangrienta. Esta vez el aspecto cuestionado era de tipo moral y no subversivo, como fue lo sucedido con Félix Tiola. En 1841 nuevamente se suscitan cuestionamientos a una obra de este tipo.

El título solo de ella inquietó a la jente de sotana i a sus adeptos. ¡Nona Sangrienta! ¿Qué significaba este vocablo? Se consultó, para averiguarlo, el diccionario de la Academia; pero no se sacó nada en limpio. Había una culebra oculta bajo esa frase. Nona significaba monja; i se había disfrazado la palabra para engañar a los incautos. La representación confirmó la sospecha. El arzobispo de Santiago, don Manuel Vicuña, creyó entonces que un deber imperioso le obligaba a dirijir al gobierno un oficio dolorido para quejarse de las piezas que se estaban dando en el teatro (Amunátegui, 1888: 254).

La Nona Sangrienta fue considerada inmoral. El arzobispo, en un oficio dirigido al ministro del interior, Ramón Luis Irarrázabal, expresó su opinión respecto de los inconvenientes de algunas obras que se presentaban en Santiago.

Con el mayor dolor de mi corazón, he recibido diferentes noticias que me aseguran la malísima elección que se está haciendo de las piezas que se representan en el teatro de esta capital, asegurándome que ellas son motivo de escándalo aun a las personas mas relajadas, por la inmoralidad que a todas luces manifiestan. Yo sería un criminal si con tales avisos permaneciese indiferente, o me contentara con llorar en silencio males tan perniciosos a la religión i la sociedad (Amunátegui, 1888: 257).

Domingo Faustino Sarmiento, quien ya había vivido en Chile durante su exilio político desde Argentina y que gozaba de una amplia consideración como intelectual en nuestro país, realizó una crítica teatral del espectáculo, en la que se destaca su criterio al reconocer que no podía juzgar bien lo que no comprendía a cabalidad. Sin embargo, o quizás por eso mismo, la crítica de Sarmiento nos otorga una idea acerca de cómo era esta Comedia de Magia: 
¿os aterran con exhibiciones espantosas; os herizan los cabellos de horror; os hacen volver la cara de asco; os deslumbran con la siniestra vislumbra de las llamas; os llena de un placer inefable a la aparición silenciosa de la luna [...]. Pues bien habeis gozado, habeis sufrido ¿Qué mas quereis? Nos abstendremos de hacer un prolijo exámen de la pieza, porque no poseemos la medida de lo bueno, de lo cabal, en este género de composiciones, y mui mal haríamos en querer medir con vara, una lonjitud que ha sido medida por estadios, millas romanas, pies de jigantes, o quien sabe que otra medida cabalística. Figurense nuestros lectores que la pieza es de májia ¿y qué entendemos nosotros de los círculos májicos ni de cómo se hacen las apariciones y las brujerías? (El Mercurio de Valparaíso, 29 agosto 1841, «Teatro», Sarmiento, s/n,: 3).

En la misma crítica, refiriéndose al teatro de la época, plantea que «es mas animado [...], mas atento a conmover los sentidos; i por tanto mas completo aunque sea mas imperfecto».

\section{MONSIEUR LEROUX}

En noviembre y diciembre de 1845 se presentó un poliorama en Santiago y luego en Valparaíso. Se trató del espectáculo de Monsieur Leroux, quien, entre marzo y junio del mismo año había presentado dieciocho funciones en Argentina.

Físico de S.M. el rey de los franceses y prestidigitador de los jardines de Tívoli. El espectador ve con deleite nacer la primavera en todos sus encantos, y seguirle las demás estaciones de año. Las representaciones del día y de la noche son tan perfectas, que la naturaleza aparece sorprendida en sus secretos (Hernández, 1928: 153).

El Progreso, primer diario de Santiago, anuncia funciones extraordinarias de Leroux. La primera, para el 30 de noviembre de 1845. Presentó prestidigitación, juegos hidráulicos y un poliorama, con el que caracterizó varias vistas proyectadas por medio de elaboradas linternas mágicas.

Vistas qe se representarán. $1^{a}$ El Puente du Gard. $2^{a}$ La torre de Nesle (apariencia de invierno) cubierta de nieve. $3^{a}$ Plaza de la Concordia en Paris apariencia de día.) $4^{a}$ Lucerna, ciudad de Suiza (representaciones de primavera, otoño e invierno.) $5^{\text {a }}$ Capilla de Hoolvrood en Escocia (representaciones de dia i de luz de luna.) $6^{a}$ La misa a media noche en el interior de la iglesia de Pisa. Aparecerá primero el interior del edificio sin una sola persona en él, i sucesivamente se le verá lleno de jente. $7^{\text {a }}$ Vista del Vesubio, del qe se verá salir umo, i en seguida se presentará en erupcion (El Progreso, 27 noviembre 1845, «Teatro», s/a, $\mathrm{N}^{\circ}$ 948: 3).

Como vemos por la breve descripción de las vistas, el espectáculo de esta tercera parte consistía en mostrar cambios escénicos por medio de proyecciones ópticas. El 5 de diciembre se comenta en el mismo diario, como noticia de última hora, la función realizada la noche anterior:

nos es grato declarar qe tanto los prestijios, como los juegos hidráulicos i poliorama, nos an parecido dignos de la concurrencia qe obtuvieron [...]. En la tercera parte de la función, la torre de Nesle, i Lucerna, ciudad de Suiza, en sus apariencias de invierno fueron de un 
efecto soberbio, como lo es siempre el espectáculo de la nieve bajo un cielo azul, después de aber pasado sobre todo dias ardorosos. Pero encima de todo esto, es preciso poner la vista del Vesuvio en erupcion. Desde el clásico concienzudo que sabe la desgracia de Plinio, asta la petimetra delicada qe se a estremecido a sus solas y sobre blando lecho con la descripción de Mme de Stael en la Corina, no a debido aber nadie en el teatro para quien el asunto de este bello cuadro no fuese conocido (El Progreso, 5 diciembre 1845, «El Progreso a Ultima ora»s/a, $\mathrm{N}^{\circ}$ 955: 3).

\section{SALONES ÓPTICOS}

En 1850 se presentó en Valparaíso un espectáculo muy anunciado de "politécnica óptica». Empezó a funcionar a mediados de 1850 y se desprende de las reseñas que llamó mucho la atención del vecindario y especialmente de profesores de establecimientos de enseñanza. Tomando como referente a la prensa del siglo XIX, Roberto Hernández elabora el relato.

Los superiores e ingeniosos aparatos opti-mecánicos que ellos poseen —decían los propios empresarios - les hacen confiar de poder rivalizar la mejor exhibición óptica de su clase, aún vista en la ilustrada Europa, sin excepcionar las famosas capitales de Londres y París. Hablábase en la primera parte del programa, de ciertos bellos cuadros exhibidos sobre un disco de más de doscientos pies cuadrados, acompañados cada uno de una corta ilustración análoga a la escena. La parte segunda tenía diversidad de ricos y curiosísimos Cromatropios, con los más extraordinarios cambios de colores y dibujos, formándose en una continuada variedad de las más expléndidas figuras, todas en el más activo estado de movimiento. Después se introducirían a la escena varios efectos diorámicos, representando el sublime efecto de las cuatro estaciones: el amanecer, el anochecer, el verano y el invierno en la Suiza. La parte tercera, hablaba de los milagros del microscopio monstruoso, mediante lo cual se exhibirían una multiplicidad de objetos variados, tanto animados como inanimados, desde 30.000 hasta 500.000 veces su tamaño natural. La cuarta parte del llamativo programa referíase a una fantasmagoría inglesa, en la cual podían verse algunas raras e ingeniosas fantasmas movedizas, nunca vistas antes en las Américas. Todo sería mostrado mediante el auxilio de esa brillante luminaria tan admirada en Europa, y conocida bajo el nombre de luz oxi-hidrógena, la que será exhibida y mostrada en público a la terminación de la función (1928: 184).

En el salón Optico (sic), en calle Bandera, que se anuncia a «media cuadra distante de la cañada» (Conjunto de Programas de Teatro $^{3}$ ), se presentan vistas nuevas, las que fueron realizadas por linternas mágicas u otro instrumento precursor del cine derivado de éstas. Las vistas eran muy variadas. Como se informa, algunos de los títulos eran Corbetas rodeadas por la nieve, La infanta de España, El Janeiro, desde la punta del Corcobado, Los Capuchinos distribuyendo á los pobres la limosna, Entrevista de Rafael con Miguel Anjelo (Conjunto de programas de Teatro). Además, se presentaban vistas de poliorama, en planos más amplios, como la Iluminación general del Arco de la Estrella.

Afiches y programas de teatro del siglo XIX, recopilados en volúmenes microfilmados de la Sala de periódicos y microformatos de la Biblioteca Nacional. 
A juzgar por los afiches de teatro de la época, por esos años en Santiago estos espectáculos tenían gran aceptación. El Salón Optico, antes Teatro de la República, realizó un afiche de difusión con fecha 15 de junio de 1853.

Este establecimiento de recreo, estudio e ilustracion acaba de recibir de Europa mil quinientas vistas de los asuntos más interesantes i variados en todo sentido, tanto antiguos como de la historia contemporánea [...].reunido el numero de cuadros recien llegados a los que tenía ya el dicho establecimiento, puede semanalmente ofrecer asuntos los más diversos i divertidos i siempre nuevos por espacio de tres años, sin que se repitan otras vistas que aquellas que se pidan. Entre las láminas de la última remesa viene una mui abundante colección de motivos de las Sagradas Escrituras i del Museo Cristiano i Galería Sagrada, obras todas copiadas de los trabajos de hombres eminentes.[...] No siendo fácil a todos los individuos de una sociedad culta, cual lo es la nuestra, juzgar de las costumbres i monumentos de diversos paises, ni poder admirar las grandes marabillas del arte i los estupendos prodigios de la naturaleza sin trasladarse al lugar en que existen, el Director de este establecimiento se ha surtido de las colecciones mas aparentes i correctas para satisfacer a la vez la curiosidad, i facilitar la instrucción: ha hecho mas, todas las historias i asuntos notables de varias épocas, i los retratos de personas de ambos sexos que puedan llamar la atención bajo cualesquier aspecto, estan reunidas a las acciones de guerra por tierra i por mar que presentan algun interes para ambos mundos. Así es, que en tan multiplicada como diversa coleccion, todos los individuos de ambos sexos, cualesquiera que sea el punto del globo en que hayan nacido, podrán encontrar infinitos motivos que despertarán agradables recuerdos i simpatías (Conjunto de Programas de Teatro).

Evidentemente, había que interesar al público santiaguino en temáticas que no le eran cercanas y, como se aprecia en los documentos antes revisados, se apelaba a «la parte selecta i de buen gusto de la Capital», invitándola a abonarse por tres meses para presenciar así las proyecciones.

En 1856, el llamado salón Poliorama anunció por la prensa su reapertura en el Pasaje Bulnes, invitando al público a ver las nuevas vistas «de la guerra de Oriente; de las fiestas que han tenido lugar últimamente en Londres i en Paris. Vistas hermosas de la Exposición de la industria» (El Ferrocarril, 15 abril 1856, «Reapertura del salón Poliorama», s/a, No 97: 3). Estaba abierto los martes, jueves y sábados, aun cuando era posible asistir otro día si es que el público interesado así lo manifestaba. La iluminación más moderna de la época era en base a lámparas de gas, las que eran utilizadas en este tipo de proyecciones.

\section{LOS POLVOS DE LA MADRE CELESTINA}

Por medio de los afiches, el 18 de diciembre de 1859 se anunció que «se está ensayando para ponerla en escena en breves dias la magnifica comedia de Magia Los Polvos de la Madre Celestina» (Conjunto de programas de Teatro), célebre obra en ese tiempo, del español Juan Eugenio Hartzenbusch, estrenada en Madrid el 11 de enero de 1841. La obra presentada en Chile fue anunciada como "GRAN FUNCION ESTRAORDINARIA DE MAJIA Y ESPECTACULO» (Conjunto de Programas de Teatro). Fue estrenada en Santiago el 24 de diciembre de 1859, en el Teatro Municipal, y se ensayó por cerca de tres meses. 
La obra requería la presencia de algunas fantasmagorías, como «un gabinete enlutado y baile de esqueletos que aparecen y desaparecen» (Hartzenbusch, 1940: 153), así como una gran transformación en la última escena, donde aparece un «vergel magnífico del personaje la Locura a la orilla del mar y luego sale el sol e ilumina la escena» (153). La intención que se anunciaba en Santiago para escenificar la obra era "ofrecer al público espectáculos nuevos, i, si era posible, algo que saliera de lo comun, i que pudiera parangonarse con lo que se ve en los mejores Teatros de Europa» (Conjunto de programas de Teatro). Dada la complejidad de la tramoya utilizada en la obra, se especificaron posibles fallas en el estreno.

No hubiera sido posible ni siquiera pensar en la exhibición de una funcion como esta, sin contar con que el Teatro Municipal tenia un maquinista apto de todo punto para ejecutar los trabajos que ella demandaba. A él pues, principalmente se le debe la confianza que asiste a la Empresa de que no ofrecerá sino un espectáculo digno de sus aspiraciones. Los defectos que en la noche de su ejecucion pudieran notarse, no se deberían en todo caso sino a la impericia de las muchas manos secundarias de que tienen que valerse los maquinistas en esta clase de piezas, i en teatros como los nuestros, en que todo es preciso crearlo. Los operarios son todos nuevos y por primera vez ejecutan un trabajo tan complicado. Esta consideración hará que se dispense una que otra falta que el tiempo solo remediará (Conjunto de Programas de Teatro).

\section{LOS MARTINETTI Y RAVEL}

En junio de 1862 se anunció por la prensa la pronta llegada de este grupo:

a quienes la guerra civil de Norte América ha echado felizmente por las playas del pacífico, saldrá del Callao en el primer vapor de julio venidero, llegará a Valparaíso el 14 del mismo mes y empezará a funcionar el 19 en el Teatro de Valparaiso. Funcionara alli hasta principios del próximo setiembre, época en que vendrá a dar funciones en el teatro de Santiago (El Mercurio de Valparaíso, 20 junio 1862, "Compañía de Raveles», s/a, No 10.453: 3).

Con la intención de definir el género de la Comedia de Magia, se aclaraba que «le es peculiar, es en parte conocido de este público, y hace innecesaria su descripción» (El Mercurio de Valparaíso, 26 julio 1862, «Teatro», s/a, $\mathrm{N}^{\circ}$ 10.484: 3). Se presentó, eso sí, el programa de la primera función. Este se dividió en cuatro partes. Junto a ejercicios aéreos, bailes pantomímicos, grandes saltos mortales, entre otros cuadros, se anunciaba que el espectáculo concluiría con la Comedia de Magia La Trompeta Mágica, la que incluiría juegos de bengala al final. Una nota informaba al público que:

la pérdida total de infinitos objetos en el naufragio del vapor Lima, a obligado a la Empresa a postergar la exhibición del Monstruo Verde y otras piezas de grande aparato. No obstante trabaja constantemente a fin de poner dichas piezas en escena la próxima semana $(E l$ Mercurio de Valparaíso, 26 julio 1862, «Teatro», s/a, $\mathrm{N}^{\circ}$ 10.483: 3).

En efecto, el vapor Lima había zarpado el 10 de julio de 1862 desde el puerto de Cobija, boliviano a la fecha, y había naufragado al día siguiente, a las 5 de la mañana, sin 
pérdidas humanas pero sí del equipaje. El comentario de teatro realizado al día siguiente de la función dice que:

el gracioso también gustó mucho y fue el que sostuvo el interés de la pantomima titulada la Trompeta Mágica. Por la primera función que nos ha dado la compañía Martinetti y Ravel, que ha sido con mui pocos ensayos, según hemos sabido, y faltándole además muchos de los útiles que perdieron en el naufragio del Lima; por estas circunstancias, decimos, no es posible juzgar a dicha compañía en su primera función (El Mercurio de Valparaíso, 28 julio 1862, «Teatro», s/a, No 10.486: 3).

Una nueva Comedia de Magia de la compañía fue anunciada profusamente en la prensa antes de su estreno: El Monstruo Verde. La escenografía, reparada en parte después del daño ocurrido con el naufragio, con nuevos accesorios realizados en Chile, aumentaba la expectación. "Las decoraciones nuevas y muchos accesorios que necesitan, el aparato y sucesivas mutaciones que hai que practicar, las danzas y juegos en la escena todo hace creer que el espectáculo será interesante y entretenido" (El Mercurio de Valparaíso, 2 agosto 1862, «Teatro», s/a, $\mathrm{N}^{0}$ 10.490: 3).

El Monstruo Verde, o El sueño Realizado, tenía infinidad de transformaciones escénicas por medio de las proyecciones ópticas, como lo detalla el programa. "Grande espectáculo de pantomima y magia decorado con toda la posible magnificencia» (El Mercurio de Valparaíso, 2 agosto 1862, «Teatro», s/a, $N^{\circ}$ 10.490: 3). Abundaban las brujas y las transformaciones en escena. Una de ellas, por ejemplo, fue la de unas flores convertidas en un Arlequín. Dentro de los muchos efectos ópticos de la obra había una ascensión y descenso de un globo aerostático y proyecciones de efectos sorprendentes, como decapitados que se mantenían vivos y la aparición de un genio. Al día siguiente de la esperada presentación se comentó la obra. En la sección crónica local del Mercurio de Valparaíso se dice que una:

concurrencia extraordinaria asistió a la función de anoche. No había un solo asiento desocupado; al contrario, se los disputaban los concurrentes tanto en la platea, como en los palcos, y anfiteatro, porque cada cual trataba de asegurarse del mejor modo posible, sin reconocer derechos adquiridos. De aquí resultaron varias disputas, que felizmente llegaron a buen avenimiento (El Mercurio de Valparaíso, 4 agosto 1862, «Teatro», s/a, $\mathrm{N}^{\mathrm{o}}$ 10.491: 3).

El espectáculo estuvo como siempre dividido en cuatro partes. Las primeras tres de varietés, con números aéreos, bailes y música. La cuarta parte fue la novedad, con el estreno anunciado:

se abrio la escena con el Monstruo Verde, pieza de muchos cuadros, de continuas mutaciones, juegos divertidos y chistosos. Estuvo bien jugada la pantomima y tambien la escena en los repetidos y súbitos cambios que hai que hacer (El Mercurio de Valparaíso, 4 agosto 1862, «Teatro», s/a, Nº 10.491: 3).

Es difícil dar cuenta de algo que no hemos visto y que sólo conocemos a través del relato escrito por otros, con casi un siglo y medio de distancia. Deducimos que en esta obra los efectos ópticos se mezclaban con los telones pintados, logrando los efectos y transformaciones escénicas. Se habla de las decoraciones de Mr. Boulet, 
distinguiéndose la de la pila con el bello fondo, que se descubrió por un momento, la del Circo, la del Castillo, y finalmente la última tan estraña como caprichosa y de gran efecto [...]. Es preciso convenir que al público le gustan las piezas de gran aparato: la función de anoche ha sido una prueba de ello, pues aunque se esperaba una buena concurrencia nadie se figuró que el Monstruo Verde atrajese jente con tanta monstruosidad (El Mercurio de Valparaíso, 4 agosto 1862, «Teatro», s/a, No 10.491: 3).

El 9 de agosto El Mercurio de Valparaíso en una breve nota da cuenta de que no ha habido «una función siquiera de escasa concurrencia» y se espera que la del día siguiente también lo sea, «sobre todo si consideramos que es el Monstruo Verde el que va a representarse, pantomima de majia, que es lo que parece preferir una gran parte del público» (El Mercurio de Valparaíso, 9 agosto 1862, «Teatro», s/a, No 10.496: 3).

Para la función del 10 de agosto se anticipó por la prensa la presentación de cuadros plásticos exclusivos de la compañía. En el anuncio de la décima función del célebre e infatigable grupo se anunció que preparaban la exhibición de sorprendentes cuadros académicos de las principales estatuas del Vaticano (El Mercurio de Valparaíso, 11 agosto 1862, «Teatro», s/a, N 10.497: 3). La función número doce de la temporada anunciaba, en una de sus partes, la "grandiosa pantomima cómica de majia, titulada: MAZULM O LA LECHUZA» (El Mercurio de Valparaíso, 22 agosto 1862, "Teatro», s/a, N 10.507: 3). El mismo anuncio describe que en la segunda escena aparece un panteón bañado por la luz de la luna y Emilio, uno de los personajes, «se encuentra rodeado de fantasmas, esqueletos, etc., etc.». Luego ocurría una transformación: la mutación del cementerio en palacio, lo que daba paso a la tercera escena: la aparición de un magnífico salón de baile en el palacio, cuyos personajes serían los fantasmas y esqueletos, transformados en caballeros y señoras. En la octava escena se vería la transformación de una mujer en esqueleto y su horrible decapitación. En la crónica local del día siguiente se comentó el espectáculo:

el difícil cambio del panteon en salon de baile fue bien desempeñado; en un instante las tumbas, destruidas arquerias, sombrios árboles, fantasmas y tristeza, se convirtió en un magnífico salon de baile, en luces, elegantes columnas, y varias parejas de danzantes rompen el baile al son de una alegre música (El Mercurio de Valparaíso, 25 agosto 1862, «Teatro», s/a, No 10.509: 3).

Durante septiembre y octubre los artistas actuaron en Santiago, en el Teatro $\mathrm{Mu}-$ nicipal, presentando el jueves 2 de octubre de 1862 Mazulm o la Lechuza. La función número veintiuno de la temporada fue el domingo 19 de octubre. Como siempre, la cuarta parte del espectáculo sería una Comedia de Magia: "por primera vez en escena la sorprendente pantomima de majia Raoul o la estrella majica, dividida en doce cuadros, grandes transformaciones, etc., etc.» (El Ferrocarril, 17 octubre 1862, «Teatro», s/a, N 2.111: 3). Estuvieron en temporada hasta el 26 de octubre. Después retornaron por unos días a Valparaíso para realizar una corta temporada desde el 9 de noviembre hasta mediados del mismo mes. Raoul o la estrella mágica no había sido presentada en el puerto en la temporada anterior, ni tampoco los cuadros plásticos. 


\section{ILUSIONES ÓPTICAS}

En el teatro de la Victoria, en Valparaíso, se anunciaba para el jueves 28 y el domingo 31 de diciembre de 1865 un espectáculo que permite comprender de mejor manera en qué consistían las muestras de ilusiones ópticas:

Esta gran invención mecánica consiste en 100 ilusiones magníficas, las cuales han traido de Lóndres a fuerza de grandes gastos, producidas por aparatos científicos de mucho costo, se exhibirá con el mismo lujo i con el mismo efecto con que se han producido en los teatros de Europa i América del Norte. El respetable público puede cree o imaginar por un momento que es una especie de panorama u otra cosa insignificante, pero no: su magnificiencia es estensa, linda i variada. Es una invención enteramente nueva, cuya base principal consiste en la ayuda del arte mecánico óptico i quimico. Vistas sobresalientes se exhiben en un telón tan gigantesco i brillante que mas de 5000 personas pueden ver de un golpe su nunca imaginada producción. Iglesias, conventos i ruinas de Roma, lindos paisajes de Italia, palacios, estatuas i puentes en Francia e Inglaterra, copias de pintura de los grandes maestros, entre ellos las celebradas producciones de Rafael de la galeria Real de Madrid. Todas estas vista se ponen delante del público con toda elegancia, cuyo efecto es asombroso. Todo el mundo debe ver esta grande i asombrosa NOVEDAD. La sensación que ha causado esta exhibición, debe su efecto a la admirable exactitud con que se hacen figuras que representan la vida verdadera. ACCIONES DE BATALLA en que miles de participantes son combinados. ASALTOS DE CIUDADES i todos los detalles de los horrores en un campo de batalla; cuyas producciones son representadas con tanta verdad i exactitud que la imajinación no puede figurarse. Solamente viéndolo puede juzgarse de su mérito. TODAS LAS ILUSIONES consisten en los efectos producidos, en que todo es original, moral i pareciendo vivo. Esto la da un valor sobre todo lo que se ha exhibido hasta ahora (El San Martín, 26 diciembre 1865, «Teatro de La Victoria», s/a, No 43: 3)

\section{JULIO BOSCO}

A fines de 1869 se presentó en Valparaíso, en el teatro de la Victoria, el prestidigitador italiano Julio Bosco, conocido como el Cagliostro del Río de la Plata. Según un afiche de la época, Bosco se había presentado, antes de llegar a Chile, en Río de Janeiro, Montevideo y Buenos Aires. Presentó en su espectáculo pruebas de física, degollamientos y, entre otros números, los Espectros Impalpables. Se mencionó también la presentación del «nuevo Linforama de vista de todos los países del mundo, fantasmas i fuegos diamantinos i otras suertes desconocidas en este país que han sido recibidas con admiracion i aplausos en todas partes donde las ha exhibido» (Conjunto de Programas de Teatro). Si bien no sabemos en qué consistía exactamente el Linforama, sabemos que Bosco hacía uso de las linternas mágicas en sus espectáculos. Un aparato óptico de proyección también usado por él en Buenos Aires fue el Silforama, una linterna mágica con vistas de movimiento de efecto sorprendente (Fernández, 1996: 315).

Un afiche de Valparaíso que anunciaba a Bosco mostraba diferentes artículos de otros diarios sudamericanos relativos al artista. Citando a la Tribuna de Buenos Aires se lee, «Bosco ardería en una hoguera, decimos nosotros, si la Inquisición existiera. Afortunadamente para él vive en un siglo en que las ovaciones han venido a reemplazar los supli- 
cios aplicados al jénio» (Conjunto de Programas de Teatro). En todo caso, la prueba que más llamó la atención en Valparaíso fue la prueba del degollado hablador:

produjo completa ilusion, por mas que se atribuya a efectos de óptica, pues no es posible tampoco atribuirlos a efectos sobrenaturales. Lo cierto es que uno ve la cabeza del degollado hablando i fumando, sin que perciba absolutamente nada de su cuerpo. La ilusion es completa (Conjunto de Programas de Teatro).

Julio Bosco se presentó en Valparaíso, Santiago y La Serena.

\section{PEYRES DE LAJOURNADE}

Otro artista que presentó Espectros Impalpables en Chile fue Peyres de Lajournade. Este ilusionista francés tuvo una gran difusión en la prensa santiaguina. Para el domingo $1^{\circ} \mathrm{de}$ enero de 1871 se anunció en el Teatro Alcázar Lírico la «GRANDE I SORPRENDENTE FUNCION DE PRESTIDIJITACION MODERNA» por el «célebre prestidigitador e INVOCADOR DE LOS ESPECTROS IMPALPABLES M. PEYRES DE LAJOURNADE» (El Independiente, 1 enero 1871, «Teatro», s/a, $\mathrm{N}^{\circ}$ 2.112: 3). Con Peyres de Lajournade se inauguró provisionalmente, el 1 de enero, el Teatro Alcázar Lírico, ubicado en la calle Moneda, entre las actuales Amunátegui y San Martín. Este artista presentó experimentos de física y pruebas eléctricas que llamaron la atención. Nos referiremos sólo al número de los Espectros Impalpables, ya que ocupaba linternas mágicas y proyección de imágenes y personas, siendo las fantasmagorías de la época. Tuvieron aceptación e interés del público también en Buenos Aires, donde Peyres de la Journade se había presentado con anterioridad. El sistema escénico consistía en el uso del principio de reflexión de luz por medio de la óptica;

pertenecía al repertorio de la llamada magia catóptrica (del griego katoptriké, derivado de katoptron: espejo; rama de la óptica que trata de las propiedades de la reflexión de la luz). La misma, basada en el empleo de espejos con o sin azogue, fondos de terciopelo negro, bambalinas y bastidores apropiados y el sabio manejo de proyectores y reflectores especiales, retomaba, trasladándola al foro teatral, una práctica de siglos anteriores en la que ya intervenían esqueletos y otros objetos simbólicos u actuaban como fantasmas personas disfrazadas (Millingan, 1945: 247, citado en Fernández 1996: 206).

En Santiago, los Espectros se anunciaron como «un maravilloso resultado de luengos estudios i larga esperiencia de los más célebres físicos acerca de los fenómenos de la óptica» (El Independiente, 12 enero 1871, "Alcázar Lírico», s/a, № 2.121:3). Se informó que Peyres de Lajournade los había estrenado en París y que tuvo presentaciones en varias capitales europeas. Antes de llegar a Chile estuvo en Lima, por diez noches consecutivas.

M. Peyres no ha omitido sacrificio ni gasto alguno para conseguir que la sociedad de esta hermosa capital tenga el placer de ver los Espectros impalpables, tales como los dos Vampiros.- La Multiplicación de lo Infinito.- El Concierto Diabólico.-La Tentacion de Santa Teresa por Lucifer.- Arrepentimiento i castigo de Júdas.- El Juicio final.- El rico avariento.Toda la Pasión de Nuestro Señor Jesucristo desde el Monte Olivete hasta su sublime Re- 
sureccion, i otras apariciones de grande i sorprendente efecto (El Independiente, 12 enero 1871, «Alcázar Lírico», s/a, N².121:3).

El espectáculo fue considerado «bellisimo i del mejor efecto» (El Independiente, 15 de enero de 1871). Los espectros iban cambiando según las funciones, desplazando en el programa a los juegos de física que se presentaron en las funciones iniciales pero manteniendo los trucos de prestidigitación. Casi siempre tenían un contenido religioso. Claro que también hubo una crítica negativa.

Las pruebas de prestidijitacion ejecutadas por M. Peyres de Lajournade fueron mui buenas; pero sentimos no poder decir lo mismo de los cuadros de la Pasion, que desagradaron estraordinariemente a la concurrencia i que el prestidijitador haria bien en no volver a exhibir mas. No son del gusto de nuestro público por su completa falta de mérito (El Independiente, 24 enero 1871«Alcázar Lírico», s/a, N².131:3).

Sin embargo, la tónica general de los comentarios fue de aprobación y deleite por el espectáculo. Las últimas presentaciones en Santiago incluyeron algunas fastasmagorías alejadas del tema religioso, como «LOS MIL i UN FANTASMAS DEL REINO DE PLUTON» (El Ferrocarril, 27 enero 1871). El 8 de febrero de 1871 Peyres de Lajournade partió con rumbo a San Felipe,

con el objeto de organizar en esa ciudad algunas funciones para las próximas festividades del 12 de febrero. Estamos seguros que obtendrá en San Felipe la misma espléndida acojida que ha encontrado en esta capital, en Valparaíso i últimamente en San Bernardo (El Ferrocarril, 8 febrero 1871, "Crónica», s/a, $\mathrm{N}^{\circ}$ 5.755: 3).

En Agosto Peyres de Lajournade volvió a presentarse en Santiago, pero esta vez acompañado con un acróbata en parte de los números: "[el] distinguido jimnasta árabe Abraham Sire» (El Independiente, 23 agosto 1871, «Teatro de Variedades», s/a, No 2.308: 3). En diciembre anunció funciones en el teatro de Variedades de "PRESTIDIJITACION,FISICA-QUÍMICA», así como «LOS TAN APLAUDIDOS I CELEBRADOS ESPECTROS VIVOS E IMPALPABLES ESPECTROS ELÉCTRICOS ESPECTROS LUMINOSOS» (Conjunto de Programas de Teatro), los que iban variando según la función.

\section{LA COMPAÑÍA GARAY}

En Quillota, en 1872, hay rastros en la prensa de funciones realizadas por la Compañía Garay, quienes tenían en su repertorio Comedias de Magia con títulos relacionados con los mundos escénicos que solía representar este género dramático.

La Compañía Garay, que hizo entonces una de sus más largas temporadas, supo explotar a maravilla algunas obras que llamaba comedias de magia, tales como el Anillo del Diablo y La Leyenda del Diablo. Con solo estas dos obras, repetidas innumerables veces, se metió un ruido de todos los diablos (Hernández, 1928: 286). 
Ese año presentaron en Valparaíso 24 funciones de la obra El Anillo del Diablo, Comedia de Magia en tres actos y en verso, del español Enrique Zumel, editada el año anterior. El texto dramático de la obra abundaba en didascalias referidas a transformaciones escénicas propias del género. Por ejemplo, en el primer acto, una estatua se transformaba en un dragón y luego por su boca salían seis furias. Estas se transformaban en juglares con liras y el dragón quedaba convertido en estatua nuevamente. En el tercer acto, un queso se transformaba en calavera y luego en un orinal. También había decapitados y cabezas que hablaban y lloraban, además de otros muchos efectos. En Santiago, a fines de 1873, podemos leer en la prensa una descripción de la obra, a presentarse próximamente en la ciudad.

De novedad estamos para esta semana en el Teatro de Variedades. La compañía Garay, tenaz en sus esfuerzos por formarse un público numeroso, un círculo que la sostenga, que la aplauda con entusiasmo, la proteja con largueza, que la juzgue con justicia, no ha reparado en ninguna clases de gastos ni jénero de sacrificios a fin de exhibir, con todo el aparato necesario, la famosa comedia de majia de Zumel, El anillo del diablo. Se han pintado decoraciones i se han encargado útiles, que aquí no era posible adquirir, a Buenos Aires. Se ha trabajado con una actividad yankee desde la cabeza a los piés, desde la cruz a la cola, como dijo el cuyano...Qué sorpresas no esperan al público? Allí aparecerá la estatua de un César decapitado, que se convertirá en horroroso dragón cuya boca escupirá furias hasta por el colmillo...Coros de demonios, cabalgatas de duendes, danzas de juglares, hombres sin cabeza i cabezas sin hombres desfilarán aquí i allá, i en medio de tan endiablada barahunda (El Independiente, 12 diciembre 1873, «El anillo del diablo», s/a, No 3.010: 3).

El programa de la primera función en Santiago fue difundido por la prensa y se anunciaba el estreno en la ciudad para el 14 de diciembre. La tramoya estuvo dirigida por Carlos Peyres. Este dato no es menor, ya que Peyres de Lajournade había presentado con anterioridad, en la tercera parte de su espectáculo de diciembre de 1871, en Santiago, un número que fue realizado por su hijo Carlos. Se titulaba el Armario Misterioso y formaba parte de la llamada trucología macabra, perteneciente a la magia catóptrica, asunto que ya se ha explicado en el registro de textos referentes a Peyres de Lajournade. En las funciones que éste realizó en Buenos Aires en el año 1866 aparecen números que también eran realizados por el «hijo mayor de Mr Peyres, una gran suspensión aérea» (Fernández, 1996: 203), "el triple sueño aéreo ejecutado por los tres hijos de Mr Peyres (204), e «ilusiones como el juego aéreo, interpretado por su hijo Charles, o la decapitación de él mismo» (212).

Las funciones de El Anillo del Diablo se presentaron en Santiago en el teatro de Variedades, cuyo constructor y empresario fue justamente Peyres de Lajournade, en 1871. El hecho de que la obra presentara efectos escénicos de proyección óptica para realizar transformaciones y mutaciones mágicas en el escenario se debió en gran medida, suponemos, al conocimiento que el hijo de Peyres de Lajournade, Carlos, tenía sobre el tema.

Todo el mundo quiere ir a ver el famoso anillo del maldito i los prodijios que ofrece la májica negra. Eso sí; no hay que asustarse. Porque el que se asusta tiene que renunciar a ver mas El anillo del diablo, perjudicando a la empresa, lo que es mucho, i perjudicándose a sí mismo, lo que es mas (El Independiente, 18 diciembre 1873, «El anillo del diablo», s/a, $\mathrm{N}^{\circ} 3.015: 2$ ). 
Un comentario de la función dice que una estatua se convirtió en dragón y que «la fúnebre i aterradora plaza de la inquisición se convirtió en palacio» (El Independiente, 20 diciembre 1873, "El anillo del diablo», s/a, No 3.017: 2-3). Evidentemente, este tipo de espectáculos no sólo estaba compuesto por juegos de proyección óptica, sino que incorporaba infinidad de recursos escénicos que permitieran crear la ilusión de una nueva y, en este caso, aterradora realidad. El Anillo del Diablo fue considerada «una pieza de gran aparato escénico, salpicada de brujería, cuyo primer personaje o actor, invisible personalmente pero mui visible en sus prodigiosos hechos, es el mismísimo demonio» (El Independiente, 20 diciembre 1873, «El anillo del diablo», s/a, $\mathrm{N}^{\circ}$ 3.017: 3).

\section{CAMBIO DE SIGLO}

En febrero de 1892 se presentó en el Teatro de la Victoria en Valparaíso el ilusionista italiano Señor Frizzo, quien dio esa noche una función de despedida con un programa bastante variado. Posteriormente se presentó en Buenos Aires, en 1893, donde sus pruebas consistieron en desapariciones de cabezas, «artísticas siluetas animadas representadas en libre proscenio o iluminando la tela a luz oxidrógena [...], cuadros escogidos de entre los más notables autores por medio de un aparato de proyección múltiple intercalados con otros efectos disolventes y ejemplares de estatuaria» (La Nación, 4 enero 1893, citado por Fernández, 1996: 345). Cuando este artista itinerante se presentó en Chile, ya tenía una carrera larga en la prestidigitación.

También en 1892, en octubre, existe un registro en Coquimbo de una sesión de espiritismo e ilusionismo. «El reputado prestidijitador señor Guillermo G. Marini, aventajado discípulo del célebre Conde Patrizio, dará próximamente dos variadas funciones de prestidijitacion y espiritismo, que prometen ser interesantes» (La Aurora, 30 septiembre 1892, «Espectáculos Teatrales», s/a, $N^{\circ}$ 50: 3). En todo caso, no hay ninguna certeza de que Marini hubiese sido verdaderamente discípulo del Conde Patricio, famoso ilusionista y espiritista que visitó Buenos Aires en 1874 y que, por medio de un cristal, reflejaba proyecciones de personas, las que eran consideradas espíritus.

El fin del siglo XIX se vio plagado de funciones de espectáculos ópticos precursores del cinematógrafo. Incluso, en las últimas décadas, era posible encontrar en la prensa avisos de venta de salones ópticos, con los implementos necesarios para instalar uno, como este aviso de la prensa de Concepción. «Se vende por un módico precio todos los accesorios para arreglar un salón óptico, componiendose de once marcos con vidrios y treinta variadas vistas» (La Revista del Sur, 3 marzo 1886. "Salón óptico», s/a, N 3.977: 3).

El 22 de agosto de 1900, en Santiago, hay un anuncio de prensa del teatro Apolo para la presentación esa noche de «la obra de gran aparato Cuadros disolventes, que la compañía del Apolo ha estado ensayando varios días con empeño» (El Mercurio, 22 agosto 1900 «Teatro Apolo», s/a, No 83: 1). Los cuadros disolventes eran imágenes escénicas que, mediante trucos de iluminación y proyección, conseguían efectos de transiciones, por ejemplo del día a la noche y también simulaciones de movimientos. El nombre de cuadros disolventes se les dio en Europa por los espectadores, dada la fugacidad de las imágenes y las transformaciones producidas entre una y otra. Fueron inventados por Henry Langdon, que los exhibió por primera vez en 1840 en Londres. 
Los cuadros disolventes que se presentaron en esa oportunidad eran cinco, el tercero de ellos se tituló "Linterna mágica». Al día siguiente se comentó que «el movimiento escénico y el lujo decorativo hacen de la pieza una novedad. Agradó, pues, a la concurencia que aplaudió bastante y rió de buenas ganas con el desfile del jénero chico» (El Mercurio, 23 agosto 1900, "Estreno de un artista en el Apolo", s/a, No 84: 2). Este género consideraba obras presentadas en un solo acto y de carácter cómico (Piña, 1999: 132). El espectáculo contó con telones pintados por el escenógrafo Javier Latorre.

Al año siguiente se anunció en Valparaíso el estreno del biógrafo. Ahí estuvo, en el teatro Nacional, «The American Biograph, de la empresa Pont y Frías, sistema Demeney, modelo de 1901, y se anunciaba con grande estrépito» (Hernández, 1928: 521). Los efectos escénicos utilizados por las Comedias de Magia son absorbidos más tarde por el cine, configurando la base de los efectos audiovisuales de las primeras películas de ciencia ficción. Se desplaza, entonces, el asombro del espectador desde el sortilegio escénico de las Comedias de Magia hacia el espectáculo cinematográfico.

Los progresos de la óptica, la mecánica y la electricidad logrados por esa época podrían haber contribuido al mayor esplendor de estas obras. Pero el cinematógrafo, al poder ofrecer más perfectos y más rápidos los prodigios y transmutaciones, las hizo caer en desuso. Efectivamente: todos aquellos artilugios no eran más que una puesta en escena de los ahora comunes efectos especiales (Fernández, 1996: 330).

Son los magos quienes continúan con la ilusión catóptrica en vivo durante la primera mitad del siglo XX, ya que el teatro, por lo menos hasta los años 60 en nuestro país, en general estuvo desvinculado de estos códigos en el ámbito escénico. A partir de esa época la experimentación en ese campo se ha ido desarrollando de manera lenta pero contundente, generando proyectos en estos inicios del siglo XXI que re-utilizan el uso de la proyección de la imagen fílmica en la escena teatral. La diferencia es que ahora la escena se vale del cine para la creación de efectos ópticos sorprendentes. Un ejemplo es el montaje teatral Sin Sangre, del grupo Cinema, estrenado en Santiago en 2006. El aspecto material más característico de esta obra es el paso de una realidad a otra por medio de una propuesta escénica que incorpora y fusiona códigos del cine y del teatro.

\section{RELACIONES DE SENTIDO}

Durante el siglo XIX, el discurso preponderante respecto de la magia en escena estaba vinculado a lo demoníaco y lo macabro. El género en cuestión, la Comedia de Magia, estaba en tensión permanente con el discurso oficial de la iglesia, así como también otros espectáculos que apelaban a la exhibición de espíritus y fantasmas. La compañía de Luis Keller, por ejemplo, explicitó por la prensa de Copiapó el carácter moral de sus funciones teatrales por medio de un permiso que le habría concedido el Arzobispo de Lima en febrero de 1865. Este, a su vez, corroboraba la autenticidad de otro certificado, expedido en el Vaticano:

el Emm. Sr cardenal vicaro de Roma, concedió permiso para que se exhibiese en la capital del órbe católico los cuadros mimo plásticos sagrados, i no debiéndose estos considerarse 
con los inconvenientes de una representación dramática, venimos en esuceder por nuestra parte permiso, para que el mensionado señor Keller pueda hacer la exhibicion de los cuadros mimo plásticos sagrados con la calidad de que en esa noche no se ha de representar ninguna otra escena profana, como son; bailes, pantomimas i petipiezas, no otros actos que desligan de la moral i relijion que profesamos (El Copiapino, 14 agosto 1865, «Teatro», s/a, $\mathrm{N}^{\mathrm{o}}$ 4.592: 3).

Existe también en el período una exaltación de tardíos motivos barrocos católicos de la Contrarreforma, como las múltiples representaciones escénicas referidas a la pasión de Cristo.

Es posible notar también que a medida que avanza el siglo el discurso tiende a utilizar una terminología que apelaba a lo científico. Por otra parte, el humor aparece en algunos textos, quizás como una forma de superar la tensión existente entre la racionalidad y la superchería. El Brujo Blanch, prestidigitador, utilizó como medio de difusión en 1869 un programa titulado periódico de circunstancias, destinado a promocionar sus presentaciones:

el Brujo, verdadero amigo de los hombres i de las niñas tambien, se propone complacerlos desechando por ahora proposiciones ventajosas que le han ofrecido de otros paises por ver un espectáculo semejante. Entre otros, los Estados Unidos le han ofrecido (i eso que estan algo apuradillos) por conducto de la catarata del Niágara, que es la cosa mas liquida que hai en el mundo, treinta mil dollars por una funcion: es decir, diez mil mas de lo que gastaron en la recepcion de los embajadores del Japon. Tal es el mérito de la funcion, i tal la ansiedad con que esperan; pero el Brujo tiene contraida una deuda de gratitud con las i los chilenos (Conjunto de Programas de Teatro).

El discurso popular aparece prácticamente ausente de los registros de la prensa. De esta manera, la gran mayoría de los espectáculos anunciados al público tenían relación con grupos internacionales, masivos, quedando marginadas manifestaciones del ámbito popular, desmedradas por la exclusión. Sin embargo, es posible dar cuenta de una realidad, aun cuando sea parcial, que nos muestra cómo las manifestaciones escénicas populares de este tipo tuvieron vigencia en nuestra sociedad. Evidentemente, dichos sectores no deben haber tenido acceso expedito a la ejecución escénica de instrumentos ópticos, pero sí lo hicieron en la proyección de sombras con luz de vela. En el ámbito popular chileno se mantuvieron las sombras chinescas, por lo menos como juego, hasta el siglo XX.

Sería interesante, en un estudio posterior, desarrollar relaciones de sentido entre las comedias de Magia, las proyecciones de vistas ópticas y los números de varieté del siglo XIX, vinculándolos con obras teatrales contemporáneas que presenten propuestas escénicas eminentemente visuales, a través del método de la comprensión dialógica, donde el sentido posee un carácter de respuesta. Siendo potencialmente infinito, sólo puede actualizarse al tocar otro sentido, ajeno. "Cada vez el sentido ha de entrar en contacto con otro sentido para descubrir momentos de su infinitud» (Bajtín 1982: 368). La motivación principal sería el hecho de poder comprender algunas de las fuentes donde se ha nutrido el trabajo de muchas compañías teatrales chilenas con fuerte contenido visual, las que, en la mayoría de los casos, realizan su trabajo de manera intuitiva y experimental, sin ninguna conciencia de tener referentes concretos, menos aún del siglo XIX.

El planteamiento donde se enmarcaría un estudio de este tipo es en el hecho de que el antiguo género de la Comedia de Magia, así como otros espectáculos escénicos visuales, 
corresponderían a propuestas inmersas en ciclos creativos, que se actualizan y refractan en propuestas teatrales contemporáneas. De esta forma, se podría ahondar en la concepción del signo, en este caso teatral, como un resultado de diferentes voces sociales, donde lo diacrónico y lo sincrónico se mezclan y donde cualquier producto simbólico de la cultura no sólo es parte de una realidad social, sino que refleja y refracta otra realidad que está más allá de su materialidad (Voloshinov, 1992: 31-3). La postura de Bajtín es que el medio semiótico es siempre histórico y social. Lo que no contesta nuestra pregunta carece de sentido. Pero no es un sentido de pregunta-respuesta convencional, desde una perspectiva gramatical o lingüística, sino que entendido como la única forma posible de diálogo, como un pensamiento abierto permanentemente.

\section{REFERENCIAS}

S/A. (1824). Diario El Avisador Chileno. Santiago, 10 abril, No 3: 22-23.

S/A. (1829). Diario El Mercurio Chileno. Santiago, 1 marzo, No XII: 575.

S/A. (1835). Teatro Gran Función. Diario El Araucano. Santiago, 6 marzo, No 234: 4.

S/A. (1835). Teatro. Diario El Araucano. Santiago, 16 abril, No 241: 4.

S/A. (1845). Diario El Progreso. Santiago, 27 noviembre, $N^{\circ}$ 948: 3.

S/A. (1845). El Progreso a Ultima ora. Diario El Progreso. Santiago, 5 diciembre, No 955 : 3.

S/A. (1856). Reapertura del salón Poliorama. Diario El Ferrocarril. Santiago. 15 abril, $\mathrm{N}^{\circ}$ 97: 3.

S/A. (1862). Compañía de Raveles. Diario El Mercurio de Valparaíso.20 junio, No 10.453: 3.

S/A. (1862). Teatro. Diario El Mercurio de Valparaíso. 26 julio, $\mathrm{N}^{\circ}$ 10.484: 3.

S/A. (1862). Teatro. Diario El Mercurio de Valparaíso. 28 julio, $\mathrm{N}^{\circ}$ 10.486: 3.

S/A. (1862). Teatro. Diario El Mercurio de Valparaíso. 2 agosto, No 10.490: 3.

S/A. (1862). Teatro. Diario El Mercurio de Valparaíso, 4 agosto, $\mathrm{N}^{\circ}$ 10.491: 3.

S/A. (1862). Teatro. Diario El Mercurio de Valparaíso, 9 agosto, $\mathrm{N}^{\circ}$ 10.496: 3.

S/A. (1862). Teatro. Diario El Mercurio de Valparaíso, 11 agosto, No 10.497: 3.

S/A. (1862). Teatro. Diario El Mercurio de Valparaíso. 22 agosto, $\mathrm{N}^{\circ}$ 10.507: 3.

S/A. (1862). Teatro. Diario El Mercurio de Valparaíso. 25 agosto, No 10.509: 3.

S/A. (1862). Teatro. Diario El Ferrocarril. Santiago, 17 octubre, $\mathrm{N}^{\circ} 2.111: 3$.

S/A. (1865). Teatro. El Copiapino. Copiapó, 14 agosto, $\mathrm{N}^{\circ}$ 4.592: 3.

S/A. (1865). Teatro de La Victoria. Diario El San Martín. Valparaíso. 26 diciembre, $\mathrm{N}^{\circ}$ 43: 3.

S/A. (1871). Teatro. Diario El Independiente. Santiago, 1 enero, $\mathrm{N}^{\circ}$ 2.112: 3.

S/A. (1871). Alcázar Lírico. Diario El Independiente. Santiago, 12 enero, N 2.121:3.

S/A. (1871). Crónica. Diario El Ferrocarril. Santiago, 8 febrero, $N^{\circ}$ 5.755: 3.

S/A. (1871). Teatro de Variedades. Diario El Independiente. Santiago, 23 agosto, $\mathrm{N}^{\circ}$ 2.308: 3 .

S/A. (1873). El anillo del diablo. Diario El Independiente. Santiago, 12 diciembre, $\mathrm{N}^{\circ}$ 3.010: 3.

S/A. (1873). El anillo del diablo. Diario El Independiente. Santiago, 18 diciembre, $\mathrm{N}^{\circ}$ 3.015: 2 . 
S/A. (1873). El anillo del diablo. Diario El Independiente. Santiago, 20 diciembre, $\mathrm{N}^{\circ}$ 3.017: 2-3.

S/A. (1886). Salón óptico. La Revista del Sur. Concepción. 3 marzo, No 3.977: 3.

S/A. (1892). Espectáculos Teatrales. Diario La Aurora. Coquimbo, 30 septiembre, $\mathrm{N}^{\circ}$ 50: 3 .

S/A. (1900). Teatro Apolo. Diario El Mercurio. Santiago, 22 agosto, No 83: 1.

S/A. (1900). Estreno de un artista en el Apolo. Diario El Mercurio. Santiago, 23 agosto, $\mathrm{N}^{\circ} 84: 2$.

Alfero, Daniela y otros. Lexicografía chilena finisecular. Onomázein 18 (2008/2): 113 137.

Amunátegui, Miguel Luis. (1888). Las primeras representaciones dramáticas en Chile. Santiago: Imprenta Nacional.

Bajtín, Mijail. (1982). Estética de la creación verbal. México D.F.: Siglo XXI.

Conjunto de Programas de Teatro. Volúmenes microfilmados, Sala de periódicos y microformatos. Santiago: Biblioteca Nacional.

Feliú, Guillermo (ed.). (1964). Gazeta Ministerial de Chile. Biblioteca Nacional: Colección de Antiguos periódicos chilenos. Santiago: Universidad Católica.

Fernández, Mauro. (1996). Historia de la Magia y el Ilusionismo en la Argentina. Buenos Aires: Producciones Gráficas.

Gómez, Rafael. (2002). La comedia de magia como precedente del espectáculo fílmico. Revista Historia y Comunicación Social 7, Universidad Complutense de Madrid: 89107.

Hartzenbusch, Juan Eugenio. (1940). Los Polvos de la Madre Celestina. Buenos Aires: Sopena.

Hernández, Roberto. (1928). Los primeros teatros de Valparaíso y el desarrollo general de nuestros espectáculos públicos. Valparaíso: Imprenta San Rafael.

Letelier, Valentín (comp.). (1887). Sesiones de los Cuerpos Legislativos de la República de Chile 1811 a 1845. Tomo IX. Santiago: Imprenta Cervantes.

Pereira Salas, Eugenio. (1974). Historia del Teatro en Chile. Santiago: Universidad de Chile.

Piña, Juan Andrés (comp.). (1999). Teatro selecto de Antonio Acevedo Hernández. Santiago: Ril.

Ruiz, Amparo y Jorge Varela. (1986). El actor oculto. Castellón: Publicaciones de la Diputación de Castellón.

Sarmiento, Domingo Faustino. (1841). Diario El Mercurio de Valparaíso, 29 agosto, s/n: 3.

Valbuena Prat, Angel. (1956). Historia del Teatro Español. Barcelona: Noguer.

Voloshinov, Valentin Nikólaievich. (1992). El Marxismo y la Filosofía de Lenguaje. Madrid: Alianza. 